PUBLICATIOIS REIATIING TO BUILDING CODES AND CONSTRUCTION PRACTICE HOME BUILDING-DUILDING VÁTERIAL SPECIFICAIIONS-MONE MAINTENANCE

\title{
GENTRAL INFORMATION
}

Some of the publications in this list have apreared ir the regular series of the National Bureau of standards. Where the price is stated, the publication may be purchased from the Superintendent of Documents by remitting either coupons obtainable from him in sets of 20 for $\$ 1.00$ and good until used, or check or money order made payable to the Superintendent of Documents, Governrent Printing office, Washington 25, D. C.

Publications listed as free may be obtained from the National Bureau of Standards.

Series letters with serial numbers are used to desi mate Bureau publications:

BH Building and Fousing publications
BMS Buildinc Materials and Structures publication
LC IEtter Circular
M Miscellaneous publication

Circular 624 and supplements (a complete list of Bureau's publications) is sold by the Superintendent of Locuments for $\$ 1.30$. Announcement of new Bureau publications is made each month in the Technical News Bulletin, obtainable by subscription, from the superintendent of Iocunents, at 50 cents per year.

\section{BUILDING CODES}

\section{Title}

Preparation and revision of building codes (1939).......... BMS19 Recommended minimurn requirements for small dwelline

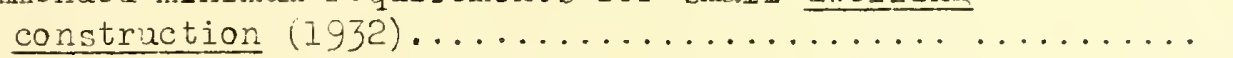
Recommended buildin code requirements for new

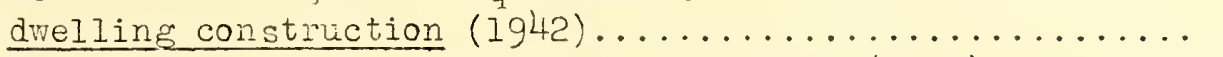
Recommended minimum requirements for plumbing (1932)........

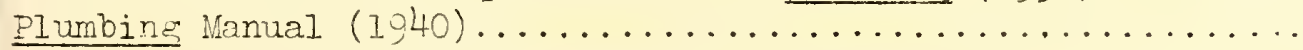
American standard building code requirements for masonry $(1944) \ldots \ldots \ldots \ldots \ldots$

Recommended minimum requirements for fire resistance in buildins's (1930). Fire-resistance classifications of building construction (1942) American standard buildins code requirements for minimun

design loads in buildings and other structures (1945).... Design and construction of buildins exits (1935)........... List of published material relating to building regulation (1945)
Series Price

BMS19 I5e

BH18 $\quad 156$

BMS88

BHI 3

BMs66

20 é

$50 \%$

20 é

$\operatorname{M174} \quad 10 \phi$

BHI 4 IOd

BMS92 $25 \%$

MI79 IOf

M151 10 ć

I0804 Free 
Title

Building matérials, buildings standards, home building:

Publications of the liational Bureau of Standaras

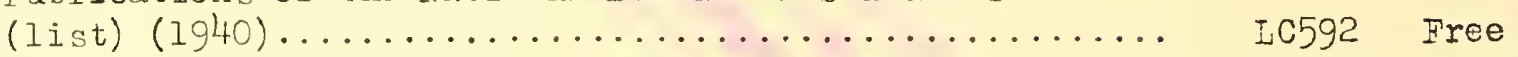

Supplement to IC592 $(1941) \ldots \ldots \ldots \ldots \ldots \ldots \ldots \ldots \ldots \ldots \ldots$. . . . . F 592 Suppl. Free

Buildins materials and structures reports (Iist) (1945)..... IC800 Free

Building materials and structures reports subject list...... SI Free

Care and repair of the house $(1931) \ldots \ldots \ldots \ldots \ldots \ldots \ldots$ BHI 5 20.

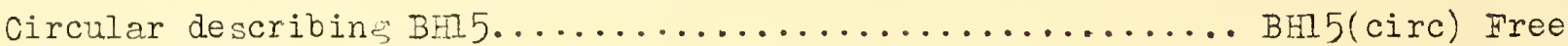

Home. heating problems: Iist of publications and

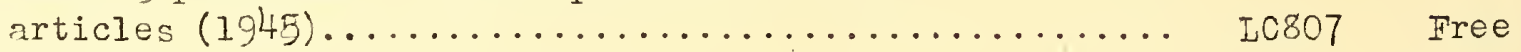

House plan services (1ist of asencies) (1945)........... IC801 Free

Iist of published material relating to home building and

maintenance (includins the more important National

Bureau of Standards publications on subjects covered)

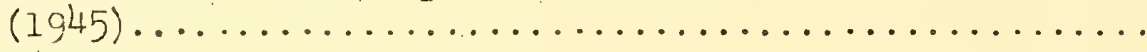

I C805 Free

Services of the National Bureau of standards to the home building industry and to the household (1936)......... SHBI Free

Standards and specifications for building and construction

materials, fixtures, supplies, and equipment (1ist) (1945) Lc808 Frea

Suggestions for possible repairs and improvements in the house and its equipment (check list) (1931)......... Ck-Sus Free

Technical information on buildirs naterials (list) (1944)... TIBM(Iist) Free

\section{MISCELIANEOUS IISTS OF PUBIICAIIONS}

Iists of publications of interest to the general public

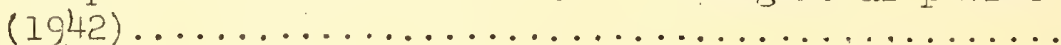

Lc696 Free

Publications of interest to suburbanites and home-builders

(Price Iist 72 , Supt. of Documents)

(1945)

PL72 Free 